\title{
When is a Haida sphinx: thinking about law with things
}

\author{
Genevieve Renard PainTeR ${ }^{1}$
}

Faculty of Law, McGill University, Montreal

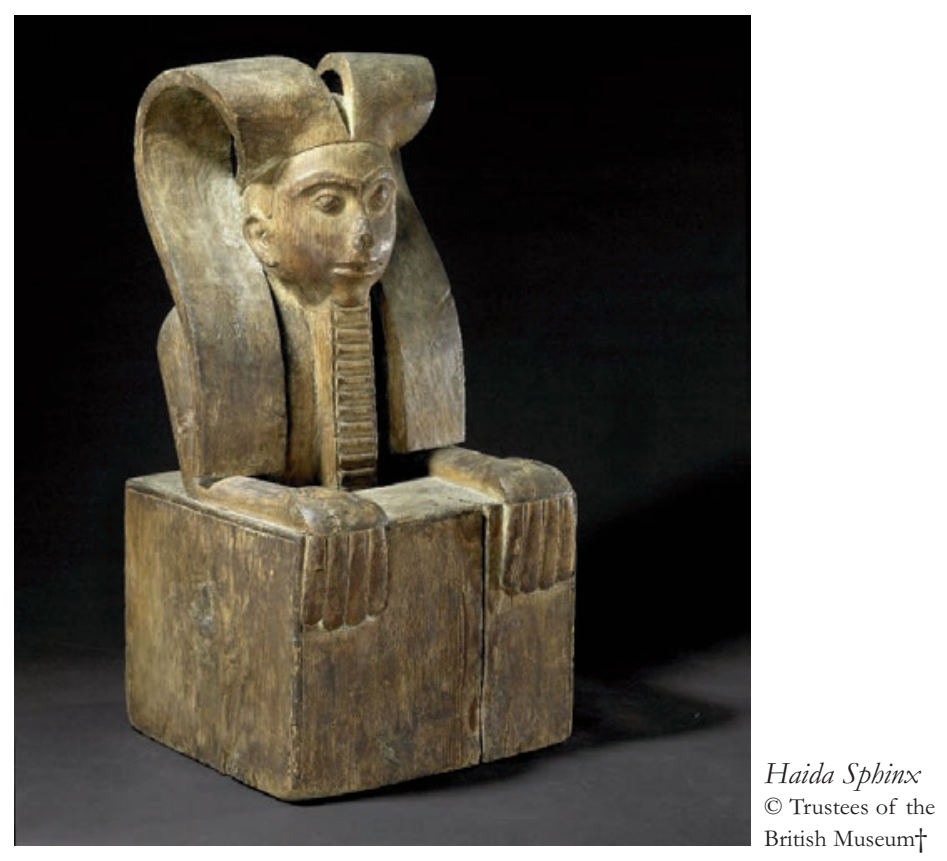

\begin{abstract}
$\underline{\text { Abstract }}$
The 'law and. . .' field of legal scholarship verges on consensus about the co-constitution between law and nearly everything else. Co-constitution raises questions about how to differentiate law from other things. The contemporary turn from words towards the material brings fresh perspective on these questions by suggesting that law's differentiation is fabricated through materiality. This article considers whether and how material techniques that differentiate law might fabricate the difference of a thing not commonly understood by Western law as law. Its focus is an object created in Haida Gwaii in the late nineteenth century and now displayed in the British Museum. It shows that while techniques common to Western law differentiate this thing, competing materialities are also at work. Furthermore, jurisdictional choices are embedded in the fabrication of this thing's difference. Understanding law as differentiated materially does not escape the social and jurisdictional forces that underpin how the matter of law comes to matter.
\end{abstract}

Keywords: materialism; law; things; Haida; Indigenous; jurisdiction; historical anthropology.

$\dagger \quad$ <www.britishmuseum.org/research/collection_online/collection_object_details.aspx?assetId=840748001\& objectId=532675\&partId=1>

1 PhD, Post-doctoral Fellow genevieve.painter.berkeley@gmail.com My thanks to Liam McHugh-Russell, Tobias Smith, Ingrid Renard, Kirsten Anker, Christopher Tomlins, Amber Lincoln, Amanda Perry-Kessaris, peer reviewers and participants at the Legal Objects Workshop, March 2017. All errors are mine. 


\section{Introduction}

Cholars of colonialism have emphasised the discourses that made space susceptible to occupation, nature open for exploitation, and lives bound for subjugation. However, colonisation required not only words, but also material things.

Enthralled by words, historians tend to leave objects to anthropologists and archaeologists. $^{2}$ Though anthropologists more readily dirty their hands, in the twentieth century, they did so not to understand the objects they encountered, but to understand how people attributed meaning to the material world. To probe the meaning of things, the field drew on Saussurian and Foucaldian theory about language, signs and symbols. ${ }^{3}$ Legal scholarship has also spurned the material. ${ }^{4}$

Recent currents have drawn the material out of the academy's backwaters. The material turn stresses embodied practices and knowledge, the ways the material world shapes us, assemblages between humans and non-human actants, the agency and vitality of non-human things, and the materialisation of multiple ontologies in the world. ${ }^{5}$ One manifestation of the material turn draws on Walter Benjamin's focus on 'the materialisation of forms and relations in things'. ${ }^{6}$ A materialist historian considers things not in ever-multiplying contexts but, instead, asks how things in constellations reveal their significance 'at the moment of . . . recognisability, which is the here-and-now'. ${ }^{7}$ Materialism in legal scholarship investigates how law is materialised through its actors, techniques and practices of creation and transmission. ${ }^{8}$

A common problem spans these disparate disciplines: differentiation. In anthropology, one approach advocates studying the material world as itself enunciating meaning, rather than being an imprint of an ideational, phenomenal world. ${ }^{9}$ Artefacts are considered not as mere illustrations of their surrounding conceptual frameworks; if that is all they are, 'one should really be studying the framework itself'. ${ }^{10}$ Instead, thing and concept are studied as one and the same. The problem is identifying the object as a 'thing in itself', as this requires determining how the thing becomes apparent from its context. For example, when Cuban diviners say their divinatory powder comes from a powder, asking how this powder is power differs from asking how it can be considered powerful. It

2 Ann Brower Stahl, 'Material Histories' in Dan Hicks and Mary C Beaudry (eds), The Oxford Handbook of Material Culture Studies (Oxford University Press 2010) 151.

3 Ibid 159.

4 Alain Pottage and Martha Mundy, Law, Anthropology, and the Constitution of the Social: Making Persons and Things (Cambridge University Press 2004) 1.

5 David Miller (ed), Materiality (Duke University Press 2006); Tony Bennett and Patrick Joyce, Material Powers: Cultural Studies, History and the Material Turn (Routledge 2010); Bruno Latour, We Have Never Been Modern (Harvard University Press 1993); Gilles Deleuze and Félix Guattari, A Thousand Plateaus: Capitalism and Schizophrenia (University of Minnesota Press 1987); Jane Bennett, Vibrant Matter: A Political Ecology of Things (Duke University Press 2010).

6 Christopher Tomlins, 'Historicism and Materiality in Legal Theory' in Maksymilian Del Mar and Michael Lobban (eds), Law in Theory and History: New Essays on a Neglected Dialogue (Hart 2016) 74.

7 Ibid 59.

8 Cornelia Vismann, Files: Law and Media Technology (Geoffrey Winthrop-Young (trans), Stanford University Press 2008); Margaret Davies, Law Unlimited: Materialism, Pluralism, and Legal Theory (Routledge 2017); Bruno Latour, The Making of Law: An Ethnography of the Conseil d'Etat (Polity 2010).

9 Amiria J M Henare, Martin Holbraad and Sari Wastell, Thinking through Things: Theorising Artefacts Ethnographically (Routledge/Taylor \& Francis Group 2007) 13.

10 Marilyn Strathern, 'Artefacts of History: Events and the Interpretation of Images' in Jukka Siikala (ed), Culture and History in the Pacific (Finnish Anthropological Society 1990) 38. 
requires establishing clear boundaries around 'powder-as-thing in itself' to avoid explaining its power as caused by context. ${ }^{11}$

In history, the differentiation problem arises because when a historian gives meaning to a thing, she either has to pretend she is in the past, capable of tapping the meaning of either the thing or its context, or she has to admit that 'meaning arises not from what is observed or its relationship with its context but from the image formed by the relationship in the observer's present between the observer and what is observed'. ${ }^{12}$ In the first case, the problem is differentiating 'the past' from the historian's imagination of it; in the second, the problem is discerning the line between observer and observed (similar to the anthropologist's problem).

In legal scholarship, the problem of differentiation may be a feature, not a bug. In contrast to an era when the 'law in the books' was viewed as neatly separated from 'law in action', a consensus now holds about the mutual co-constitution between law and nearly everything else. In fact, for some thinkers disenchanted by concept-context relationality as a rubric for studying law, law can be theorised 'as' economy, archive, language, image and so on. ${ }^{13}$

Some scholars worry that if everything is co-constituted with law and 'the conventional markers of law's differentiation . . . are all artificial reifications', there is no longer a category called 'law'. ${ }^{14}$ Others suggest that the material turn offers a solution. Given that law is held to be different from other things, instead of grasping for the interior or exterior of that thing, we can ask how its purported differentiation emerges. How is law's difference fabricated? The answer is: materially. Files and cabinets, archives, documents, courtrooms, and technicalities like judicial recourse to categories, tools, and tests: these are the materials through which law is differentiated. ${ }^{15}$ Instead of presuming law and inquiring about materiality, we should "begin with the extensive potentialities of "materiality" and ask what becomes of "law" if we try to hold those potentialities open'. ${ }^{16}$

If materiality fabricates the law's categorical differentiation, what happens if we start with a thing not denominated as law, a thing regarded as exterior to law, and ask about the effects of those same materialities? This essay explores this possibility through an inquiry into a thing in the British Museum. First, by considering some of the materialisms that produce law's differentiation - time, precedent and categorisation - the analysis reveals that the material techniques common to law also fabricate the difference of a not-law thing. This either makes the thing 'law', or it raises questions about whether materiality distinguishes law specifically (which, recall, is key to understanding how law is differentiated).

Second, this analysis yields interesting purchase on the question, "Can "things" be "Indigenous"?'17 When a thing is taken as if it were law, the question of a thing's indigeneity emerges as a question of jurisdiction, with actors who ask, listen, or answer,

11 Henare et al (n 9) 5-6.

12 Tomlins (n 6) 66.

13 Christopher Tomlins and John Comaroff, “Law as . . .": Theory and Practice in Legal History” (2011) 1 University of California Irvine Law Review 1039, 1041.

14 Tomlins (n 6) 67.

15 Annelise Riles, 'A New Agenda for the Cultural Study of Law: Taking on the Technicalities' (2005) 53 Buffalo Law Review 973.

16 Alain Pottage, 'The Materiality of What?' (2012) 39 Journal of Law and Society 167, 180.

17 Rodney Harrison, Sarah Byrne and Anne Clarke, Reassembling the Collection: Ethnographic Museums and Indigenous Agency (School for Advanced Research Press 2013) 8. 
thus recasting an empirical question into a political and ontological one. Meanwhile, the thing itself remains enigmatic.

\section{The thing}

The British Museum obscures colonisation by displaying found objects as principally representing their originating communities, rather than as representing the imperial circuits that brought objects to London and, in doing so, helped to form modern Britain. ${ }^{18}$ In search of a rare display of the materiality of colonisation, I combed the online catalogue for an object that seemed to be a hybrid of European and non-European influences. After hours of scrolling, an image appeared that differed from all the masks, bowls, hats and tools I had seen. I gazed at a photograph of an object carved of wood. The object has a human face. Two curved shapes swoop around its face, and a serrated narrow rectangle protrudes from its chin, resembling a beard. Extending from each shoulder, limbs ending in four digits clasp the edge of the block holding the figure. The website describes the thing as a 'sphinx figure made of wood (pine), plaster' and comprises 15 photographs and 18 fields of information, including the following '1896 Register comment':

. . . in a deserted village near Masset, Queen Charlotte Islands. Found in a pit in a house. Carved by Simeon Silthda, a Haida, from a picture in an illustrated Bible shown him by Rev. Wm. Collison between 1874 \& 1878.

There is an additional note that the object was obtained from '[Clarke]'. ${ }^{19}$

The webpage initiated a centrifugal legal archaeology to find the people, places, things and processes drawn together by this record. ${ }^{20} \mathrm{~A}$ subsequent gallery visit complemented this investigation. Do law's materialities - namely, temporality, precedent and categorisation - fabricate this object's differentiation?

\section{Temporality}

The common law likes time to be smooth, plodding and orderly. The common law acts on time, through 'the production and organization of time as past, present, and future'. ${ }^{21}$ Furthermore, it has temporalities internal to it. ${ }^{22}$ Cornelia Vismann reverses the etiology: law does not reflect a homogeneous time; rather, time and law are both shaped by the media for recording and archiving. Files in loose-leaf collections 'predestine[s] codices for the retroactive compilation of legal texts'. ${ }^{23}$ Registers enable chronological ordering of documents. Thus, chronological time emerges as a material site through which the differentiation of law occurs.

Turning to our object, time helps to fabricate the difference of this thing as emerging from, and representative of, a past time. The catalogue record refers to a kind of time in which the artefact's voyage is traced continuously from its creation, between 1874 and

18 Nicholas Thomas, 'The Museum as Method' (2010) 33 Museum Anthropology 6, 9.

19 British Museum Collection Online, <www.britishmuseum.org/research/collection_online/ collection_object_details.aspx?objectId=532675\&partId=1\&people=40813\&peoA=40813-3-31\&page=1>.

20 Angela Fernandez, 'The Lost Record of "Pierson v. Post," the Famous Fox Case' (2009) 27 Law and History Review 149.

21 Renisa Mawani, 'Law as Temporality: Colonial Politics and Indian Settlers' (2014) 4 University of California Irvine Law Review 65, 69.

22 Kunal Madhukar Parker, Common Law, History, and Democracy in America, 1790-1900: Legal Thought before Modernism (Cambridge University Press 2011); John Borrows, 'Frozen Rights in Canada: Constitutional Interpretation and the 'Trickster' (1997) American Indian Law Review 37.

23 Vismann (n 8) 43. 
1878, its acquisition in 1896, and its display. This transparent, uninterrupted time is the backdrop against which fieldwork expeditions seek to bring back 'objects which have the properties of being mobile but also immutable, presentable, readable' ${ }^{24}$

The 1896 Register comment notes that the object was found 'in a deserted village near Masset'. ${ }^{25}$ Between 1876 and 1884, in the aftermath of a deathly smallpox epidemic, survivors abandoned aan $^{26}$ and moved across the inlet to Masset. ${ }^{27}$ The object, one infers, was found in the 'deserted village' of yaan during this eight-year period. ${ }^{28}$

The catalogue reports that August Wollaston Franks donated the object to the museum. Franks was Keeper of the British Museum. He never travelled outside Europe, meaning that the object was shipped to him from Masset. ${ }^{29}$ A prolific collector, he may have held the object in his personal collection before donating it in 1896. Upon donation, the object entered a collection bequeathed by Henry Christy. After Christy's death, artefacts were entered into the museum's collection according to a system designed by Franks and C H Read to impose a taxonomic order on Christy's sprawling antiquarian collection. This new system ensured a record of 'how, from whom and, if relevant, at what price an object had been obtained', thus inscribing time ordered by a chain of custody. ${ }^{30}$ The object's accession number (Am1896,-.1202) and the Register comment demonstrate that it was catalogued under Franks' system. Today, hyperlinks in the online catalogue allow artefacts to be grouped across categories like 'Ethnic Name', while galleries gather artefacts in purposive displays. By imposing order on 'the confusion ... . the scatter, in which the things of the world are found', chronological time as a material makes dispersed things into differentiated objects in which 'the world is present, and indeed ordered'. 31

Although a smooth, sequential time aims to differentiate this thing, mystery and incoherence also transect its story. A wavy, fractured time muddies chronology's role in differentiating this thing. ${ }^{32}$

First, there is a 20-year gap in this thing's resumé. Where was it between its creation and its donation in 1896? Weighing 18 kilograms and measuring 74.5 by 36 by 37 centimetres, the object is too big to overlook, forget, or pocket. The period of its disappearance coincides with the zenith of the scramble for artefacts by private collectors and museum-commissioned anthropologists. ${ }^{33}$ Was this object abandoned by yaan's erstwhile residents, only later to be prized by collectors?

24 Bruno Latour, 'Drawing Things Together' in Michael Lynch and Steve Woolgar (eds), Representation in Scientific Practice (MIT Press 1990) 26 (original emphasis).

25 Masset is on the northern tip of Haida Gwaii (formerly the Queen Charlotte Islands, British Columbia, Canada).

26 Spellings follow conventions adopted in Robin Kathleen Wright, Northern Haida Master Carvers (University of Washington Press/Douglas \& McIntyre 2001) 334.

27 John R Henderson, 'Missionary Influences on the Haida Settlement and Subsistence Patterns, 1876-1920' (1974) 21 Ethnohistory 303, 308.

28 Wright (n 26) 293.

29 J C H King, 'Franks and Ethnography' in M Caygill and J Cherry (eds), A W Franks, Nineteenth-Century Collecting and the British Museum (British Museum Press 1997) 143.

30 Jill Cook, 'A Curator's Curator: Franks and the Stone Age Collections' in Caygill and Cherry (n 29 ) 121.

31 Walter Benjamin, Howard Eiland and Kevin McLaughlin, The Arcades Project (Harvard University Press 2003) $\mathrm{H} 4 \mathrm{a}, 1 ; \mathrm{H} 2,7$.

32 Christopher Pinney, 'Things Happen: Or, from Which Moment Does That Object Come?' in Miller (n 5).

33 Douglas Cole, Captured Heritage: The Scramble for Northwest Coast Artifacts (University of Washington Press 1985) 286. 
The object was collected by 'W.W. Clarke'. We know little about him. A 'Walter William Clarke' worked as a compositor in Victoria between 1891 and 1897.34 Another 'Walter William Clarke' chaired a survey of a valley in British Columbia's interior in 1892.35 No evidence puts either man near Haida Gwaii. A more likely candidate is a 'Walter Clarke' of Victoria, a machinist who, in 1879, made a 'weaving loom . . . [for] the Metlakatlah Mission'. ${ }^{36}$ This put Clarke in contact with William Duncan, the reverend at Metlakatla. Duncan knew Reverend W H Collison, the missionary mentioned in the 1896 register. This connection may have offered Clarke the occasion to collect Haida artefacts.

We do not know when the object was collected from yaan. Collector James Swan hired seasoned guide James Deans and Edenshaw, a chief with knowledge of the villages deserted by his people. Given their assistance, Swan probably visited yaan in 1883 and could have collected the abandoned carving. His expedition to the area yielded 'five cases with over two hundred ethnological and natural history specimens'. 37 James Deans worked for other collectors. In an expedition in 1897, Deans guided George Dorsey's party for a stop at yaan. ${ }^{38}$ In 1892 , Deans amassed three boxcar loads of Haida material on a commission for Franz Boas. ${ }^{39}$ Given Deans' knowledge of yaan, he would probably not have overlooked the object when collecting for Boas. If Deans had seen the object in 1892 , or Swan had seen it in 1883, they probably would have collected it. This implies that the object had been retrieved from its pit by 1883 , and certainly by 1892 . Perhaps it was found by 'Clarke', possibly the machinist in contact with Duncan in 1879. If so, why did Clarke wait four to 17 years before offering the object to the British Museum, during a period of high demand for Haida artefacts?

The gallery display suggests that Reverend John Henry Keen donated the object to the museum. The caption contradicts the catalogue's account of a donation by A W Franks. Reverend J H Keen arrived in Masset in 1890.40 A passionate, respected ornithologist and entomologist, Keen hastened on his arrival to send a package of specimens of invertebrates to the Natural History Museum. ${ }^{41}$ In 1898, Keen sold 47 Haida artefacts to the British Museum. Four of those artefacts show that Keen was in contact with C H Read, the curator of the museum's Christy Collection. Given Keen's own collecting and his connections to the milieu, one wonders why Keen did not collect the object himself. This buttresses the thesis that the object had been collected before Keen's arrival in 1890 . We cannot know with certainty.

The gallery caption placing Keen on the scene probably originates from a misinterpretation ${ }^{42}$ of Wright's suggestion that, when the object was donated, information about the carving's origin 'must have come indirectly from Collison ... .

34 'Clarke, Walter William’ <https://westendvancouver.wordpress.com/biographies-a-m/biographies-c/clarkewalter-william-1864-about-1916/>.

35 Walter W Clarke, 'Diary' < http://search.bcarchives.gov.bc.ca/diary-15>.

36 'The Loom for Metlakatlah' Daily Colonist (Victoria 13 December 1879) 3.

37 Cole (n 33) 40.

38 Ibid 170.

39 Ibid 123.

40 Melville H Hatch, 'A Biographical Memoir of the Rev John Henry Keen' (1957) 11 Coleopterists Bulletin $62,62$.

41 Spencer G Sealy, 'The Reverend John H Keen's Observations of Birds and Unpublished List from the Queen Charlotte Islands (Haida Gwaii), British Columbia, 1890-1899’ (2016) 26 British Columbia Birds 16, 18.

42 Correspondence on file with author.

43 Wright (n 26) 293. 
through the Reverend J.H. Keen, the missionary in Massett' in 1896. ${ }^{43}$ Wright extrapolates from the 1896 register to paint a picture of Keen and Collison discussing the object.

The museum's information systems, coupled with extrinsic evidence, project a continuous, visible thread through time, but these systems simultaneously elicit disruptive and opaque evidence. An account of a homogeneous time is at work in differentiating this thing as a thing, but not exclusively. Another disjointed, heterogeneous time is also at work.

\section{Precedent}

For the common law, precedent 'binds or attaches persons, places, events and activities to the body of law', 'hold[s] the body of law in place' and 'crafts and transmits relations of authority'. ${ }^{44}$ It is commonly believed that precedent transmits reason, in the form of legal principles that endure across place and time. Rather, precedent transmits institutional arrangements and forms of address that differentiate law and through which law is materialised and fabricated. ${ }^{45}$ As such, precedent constitutes the common law's technology for doing history. ${ }^{46}$ It resembles a Benjaminian materialist method, as cases in the present day are decided in relation to past cases, and the significance of 'the contemplated object is not enlivened by the relationalities within which it allegedly belongs, the relationalities of its time, but by the fold of time that creates it in constellation with the present'. ${ }^{47}$ The common law worries little about a case's correct historical context, leaping enthusiastically to juxtapose odd fragments of a nevercompleted past as emergent within present-day concerns. Precedent holds the law apart from history and thus materially fabricates law's differentiation.

This technique is at play regarding our object, but, as with temporality, in an incomplete way. The 1896 Register describes the object as having been created based on a missionary showing an illustrated Bible to a Haida carver. The gallery caption glosses on this to say that the object 'captures a moment of cultural dialogue in the 19th Century between existing and newly arriving cultural traditions on the islands of Haida Gwaii on the Northwest Coast of North America'. The combination of the 1896 Register, the acquisition history and the gallery caption enrols this object into a story about HaidaEuropean relations that represents a 'moment of cultural dialogue', in a modern era attuned to museums as sites of enduring colonial expropriation. ${ }^{48}$ We know that this object was made during or shortly after Collison's three-year term at Masset, a term that yielded only five conversions to Christianity. ${ }^{49}$ When it was made, how much 'dialogue' did this object represent? When the 1896 register was penned, could the object have represented the uphill battle to win Christian converts? The catalogue cites several 'cases' that could have been precedent to other presents. Those cases are arrayed in a presentday story of cultural dialogue through the institutional arrangements and historiographical techniques of museum curation.

The catalogue reflects a mode of history that makes the object's past a servant of the present, but the object's materiality resists with its own historical method. The 1896

\footnotetext{
44 Shaunnagh Dorsett and Shaun McVeigh, Jurisdiction (Routledge 2012) 67.

45 Ibid 69.

46 Renisa Mawani, 'Law's Archive' (2012) 8 Annual Review of Law and Social Science 337, 354.

47 Tomlins (n 6) 59 (original emphasis).

48 Cara Ann Krmpotich and Laura L Peers, This Is Our Life: Haida Material Heritage and Changing Museum Practice (UBC Press 2013) 25.

49 Wright (n 26) 228; W H Collison, 'Journal' Northern BC Archives, Archdeacon W H Collison fonds, Item 2009.7.2.7 <https://search.nbca.unbc.ca/index.php/journal-of-w-h-collison>.
} 
Register records the piece as carved by 'Simeon Stilthda'. 50 'Simeon Stilthda' was a carver and, as such, was one of the 'high-ranking members of the noble class - chiefs who inherited their rank along with the privilege of being trained as artists' ${ }^{51}$ sdiibldaa is likely to have been rescued by Reverend Collison from a fire into which he had thrown himself in despair over his son's death. ${ }^{52}$ Alfred Adams, a Haida consultant of anthropologist Marius Barbeau, recalled sdiibldaa to be a carver from yaan and

... one of the old Haidas, a good man with clean living. He was one of the old chiefs who had capacity for high respect. He lived on to old age. When Archdeacon Collison came here he accepted him right away. But he went on carving just the same. ${ }^{53}$

The 1896 Register's record of authorship was unusual for the nineteenth century, when accession records focused on cultural group and disregarded artists. ${ }^{54}$ The artists behind many artefacts were uncovered in an attribution movement in the 1980s. ${ }^{55}$ Art historian Bill Holm attributed this object to another artist, gwaay'tiibld, until 'new information received as his article went to press prompted Holm to add a footnote pointing out that ... [the] figure . . had documentation indicating that it was carved by Simeon Stilthda'.56 This documentation was presumably the 1896 Register, apparently inaccessible to researchers until the 1980s. It was actually a comparison between masks already attributed to sdiibldaa and this object, 'with the knobby chin, rounded orb with small eyes, open eyelids, pinched nose, and low naturalistic ears', that led to the conclusion that sdiibldaa had carved this object. ${ }^{57}$ Thus, the object's maker was identified through its material characteristics and its juxtaposition to other objects, rather than through an existing, arguably dispositive archival record. This is history formed from the synchronous juxtaposition of material things - bringing 'together what belongs together; by keeping in mind their affinities' - rather than formed through the past rising up to reveal its significance to the present, or the present seizing the past. ${ }^{58}$

As in the discussion of temporality, precedent is at work to fabricate this object as the thing displayed in the British Museum. But the 'case law' brought to bear on the matter is not conclusive, as in legal reasoning. Juxtapositions of material evidence provide another mechanism through which this object is differentiated.

\section{Categorisation}

Through categorisation, 'we name, locate and order the body of law'59 and, in doing so, fabricate the differentiation of law. Categorisation is what Western law does in sorting persons from things and civil disputes from criminal ones. Categorisation also shapes the common law. For example, tort law, now understood as a substantive legal domain,

50 Various spellings exist in the archives: Sti'lta, Stilte, Stelta, Stilta, Steltha, Steelta, Steel-tah, Steta, Stiltha, Steilta, Stiltae, Stilthda. Wright (n 26) 357.

51 Ibid 5.

52 Ibid 297, 303.

53 Ibid 301.

54 Krmpotich and Peers (n 48) 11.

55 Robin Kathleen Wright, 'Two Haida Artists from Yan: Will John Gwaytihl and Simeon Stilthda Please Step Apart?' (1998) 23 American Indian Art Magazine 42.

56 Wright (n 26) 289.

57 Ibid 293.

58 Benjamin et al (n 31) H4a, 1.

59 Dorsett and McVeigh (n 44) 71. 
emerged through the work of jurists gathering numerous, disparate forms of actions into a single category. 60

Our object is a site of categorisation as a technique to produce differentiation. But, in contrast to the essay's earlier sections, law cannot be kept at bay because Western legal concepts now become integral to the object's categorisation. The database record inscribes the object in Western law through the categorisation of actors and their relation to the object. The figure becomes a thing with a producer ('Simeon Stilthda'), collector ('W.W. Clarke') and donor ('A.W. Franks').

By listing the Western legal relationships connecting individuals to the object, the catalogue qualifies the carving as a 'thing' and axiomatically not a person. Categorising persons and things was integral to colonisation. The battle against idolatry waged by Christian missionaries was a battle over the distinction between persons and things, a battle fought through efforts to treat the diseases brought by Europeans. Smallpox had swept the islands' villages in 1862 , leading to as much as a 72 per cent population loss. ${ }^{61}$ The bodies of the sick became a material site for campaigns aimed simultaneously at Christian conversion and ascension to the status of civilised Crown subjects. The not-yetconverted/not-yet-civilised were in a borderland between person and thing. That categorisation in turn transformed missionaries from working on (ideal) souls to working on (material) bodies.

Reverend Collison, the first missionary in Masset, immediately pegged the medicine men as his adversaries and fought to banish their rattles and other regalia. Collison's counter-attack relied on materials, in his recourse to medicines, the Bible and illustrations. ${ }^{62}$ Before learning the Haida language, Collison conducted services by displaying 'large scriptural cartoons' and delivering a message based on these illustrations. ${ }^{63}$ Apparently convinced by Collison's methods, one medicine man asked for 'scriptural illustrations' or a Bible so that he, too, could cure the sick. Collison heard the request as evidence of his failure to explain the immaterial sources of God's mercy. ${ }^{64}$ Missionary-led colonisation turned on defining things as things and insisting that other things, like a Bible, were material props for immaterial faith.

Although legal categorisation fabricates this thing's differentiation, it is a two-sided coin. For just as things were categorised as objects to be owned rather than causes of healing, these things in turn categorised missionaries as collectors and traders. Missionaries were integral to the traffic of artwork out of the region. They collected an estimated half of the ceremonial objects in the combined collections of 28 museums in North America and Europe. ${ }^{65}$ Beyond their direct role as traders, missionaries convinced people to relinquish artefacts. Collector James Swan lamented areas in which 'the people

60 Ibid 74.

61 Jason Grek-Martin, 'Vanishing the Haida: George Dawson's Ethnographic Vision and the Making of Settler Space on the Queen Charlotte Islands in the Late Nineteenth Century' (2007) 51 Canadian Geographer $373,389$.

62 Marcus Tomalin, "My Close Application to the Language”: William Henry Collison and Nineteenth-Century Haida Linguistics' (2007) BC Studies: British Columbian Quarterly 93.

63 W H Collison, In The Wake of the War Canoe: A Stirring Record of Forty Years Successful, Labour, Peril and Adventure amongst the Savage Indian Tribes of the Pacific Coast, and the Piratical Head-Hunting Haidas of the Queen Charlotte Islands, BC (Musson Book Company Ltd 1916) 127.

64 Ibid 183-4.

65 Joanne MacDonald, 'From Ceremonial Object to Curio: Object Transformation at Port Simpson and Metlakatla, British Columbia in the Nineteenth Century' (1990) 10 Canadian Journal of Native Studies 193, 194,201 
are not anxious to sell their curiosities, as they have not yet come under missionary influence'. ${ }^{66}$ The categorisation of artefacts as signs of idolatry and as tradable goods pulled the missionaries into a global market. Categorisation cuts a line that differentiates what is outside the category, not only what is inside.

Employed as legal technique, categorisation seeks to turn the endless dispersion of quotidian drama into commensurable units; everything within the category becomes the same. ${ }^{67}$ This battle for totalising taxonomies is waged but never won, because for every 'thing' categorised by law, there is 'always an uncontained remnant . . . the . . obstinate remainder that defies the perfection of equivalence'. ${ }^{68}$ The excess is as germane to categorisation as what is within the category. Thus, the remnant is part of material techniques of differentiation.

With our object, its differentiation is fabricated by an excess or remnant: absence specifically, an absent lion's body and an absent Bible. The object is simply a carved head and torso, with limbs and shoulder blades, resting on a wooden block. It has no lion's body. What makes it a sphinx? If it is a sphinx, it is because some viewers replace an absent body with a form familiar from Greek or Egyptian antiquity. The phantom lion's body is then assembled with the head and torso, the database record ('Sphinx figure') or gallery caption ('Haida Sphinx'), and the Register comment about a missionary showing a Bible to the artist. Conjunction between object, label and imagination nominates the thing a 'sphinx'.

In search of the sphinx, I tried to locate an illustrated Bible that Reverend Collison might have carried in 1874; so did art historian Robin Wright. Failing to find Collison's Bible, Wright reports that the Bible of Reverend Duncan, the missionary in Metlakatla, contains a 'three-quarter view sphinx figure in the background of an Egyptian scene from the Book of Genesis'. ${ }^{69}$ This is awkward news for our object, which has human shoulder blades and no backside. Wright bravely suggests that perhaps Collison's Bible contained a frontal image of the sphinx, causing sdiibldaa to produce this incomplete rendering, or that sdiibldaa had seen the sphinx image in Duncan's Bible. ${ }^{70}$

We will probably never know. But the impulse to find the Bible that sdiibldaa saw when he made this figure shows how the Bible is part of its categorisation. Seeing the sphinx in the Bible is a way to narrow the gap between the multiple presences in the past, and thus to minimise the object's inscrutable remnant. The thing cannot be simply the shape that it is: it must be an incomplete sphinx from a named missionary's Bible. Categorising the thing as a sphinx conjures an absent lion's body, an absent Bible and an absent act of copying from a Bible. These immaterial absences render the object legible as a Haida artistic response to European illustrations, Christian presence and cultural dialogue.

\section{When the empirical is jurisdictional}

I chose this thing out of all the other 'Haida objects' in the museum's catalogue because it looked like it was a hybrid, the fruit of a colonial encounter between the Haida and Europeans. This made the other objects, a contrario, 'Haida'. In that distinction, I

66 Cole (n 33) 43.

67 Christopher Tomlins, 'Why Law's Objects Do Not Disappear: On History as Remainder' in Andreas Philippopoulos-Mihalopoulos (ed), Routledge Research Handbook on Law and Theory (Routledge forthcoming 2018).

68 Ibid.

69 Wright (n 55) 47.

70 Wright (n 26) 357. 
unwittingly reproduced an ordering logic of the nineteenth century, when North America's Indigenous people were seen as 'vanishing races' who would be overcome by a tide of civilisational progress, and 'pure' Indigenous artefacts were prized over those 'degraded' by contact with the present. ${ }^{71}$

What does it mean to look for a Haida thing? Can a thing be Indigenous? ${ }^{72}$ As early as 1820 , the Haida made and sold tobacco pipes to fur traders. ${ }^{73}$ Artists who had long traded their work with nations on the mainland welcomed this new market. ${ }^{74}$ When missionaries arrived, they encouraged artists to make masks and other artefacts for sale. ${ }^{75}$ Because Haida law prohibited the sale of ceremonial goods, a Kaigani Haida developed a facsimile mask specifically for export that was never ceremonially dedicated. It became the prototype for all Haida masks for sale in the nineteenth century, including masks by sdiibldaa. ${ }^{76}$ These masks were a Haida response to a market of non-Haida buyers. In this light, any Haida artefact - not just a sphinx copied from a Bible - might materially represent nineteenth-century colonial encounters. The categorical distinction between 'Haida' and 'not-Haida' things collapses.

In 2009, a delegation of Haida researchers also looked for 'Haida things' in the British Museum, but for them, the search was an opportunity for 'reconnecting to these objects and to the ancestors who made them after their long separation from the community'. ${ }^{77} \mathrm{~A}$ century-long period of absence coincided with the objects' classification in the material, legal, and discursive registers of the society that had acquired them, and with the classification of the Haida as Indigenous. ${ }^{78}$ Some Haida delegates to the museum related to the objects as kin, displaced or in diaspora. ${ }^{79}$ The objects were still 'Haida', as the catalogue asserts, but their significance and even their status as things changed when drawn into present-day relationship with Haida artists and researchers. The notion of a 'Haida thing' remains open, with potential to act, assemble and signify new meanings in the future.

The collapse and openness of the category colour the question, 'Is this a Haida thing?', as one in which the empirical and jurisdictional are intertwined. Empirical questions contain epistemological and ontological blueprints, and those blueprints are also legal and jurisdictional. ${ }^{80}$ Issues once categorised as empirical become questions of lawful relation. For example, a comment about artistic attribution by Haida artist Freda Diesing (1925-2002) becomes legible as a jurisdictional statement:

Oh, I see you art historians and anthropologists have finally got it right! You can now distinguish between the work of Gwaytihl and Stilthda . . . Did you know that Stilthda was my great grand uncle? My granny told me the missionaries encouraged him to make masks [to sell] on the condition that they would never be used at dances or potlatches. ${ }^{81}$

71 Grek-Martin (n 61) 375, 392.

72 Harrison et al (n 17) 8.

73 Wright (n 26) 248.

74 Daina Augaitis, Lucille Bell and Nika Collison, Raven Travelling: Two Centuries of Haida Art (Vancouver Art Gallery 2006) 65.

75 Wright (n 26) 293.

76 Augaitis et al (n 74) 100.

77 Krmpotich and Peers (n 48) 94.

78 Ibid 11.

79 Harrison et al (n 17) 12.

80 Genevieve Renard Painter, 'A Letter from the Haudenosaunee Confederacy to King George V: Writing and Reading Jurisdictions in International Legal History' (2017) 5 London Review of International Law 7, 48.

81 Augaitis et al (n 74) 100. 
In juxtaposing what art historians and anthropologists know and what she and other descendants have known, Diesing is doing jurisdictional work through an empirical assertion about how a thing's origins are known. By asking 'Which law?' rather than 'How does law apply to this thing?', jurisdiction is a technical means to define how humans and non-humans belong to a potential plurality of legal orders, ontologies and epistemologies. Jurisdictional inquiry reveals how changes in the categorisation of this object - from a curio proving missionary presence to a displaced kin - are changes of jurisdiction, meaning that law is internal to the object. If the material and jurisdictional are so thoroughly enmeshed, we are back to square one in our efforts to figure out how law is differentiated through the material.

\section{Conclusion}

Saying that the law is differentiated materially seems not to circumvent the question of 'Whose law?' That question is internal to the understanding of materiality that is hypothesised to fabricate law's difference. The division between material and immaterial, real and ideal, underlying the materialist turn is an attribute of Western epistemology and ontology, which are themselves historical. Even the question about the relationship between law, materialism and history starts from an 'inside (Western) law' perspective. This is not a prelude to an argument about the slippery slope to legal pluralism. Rather, it is an observation that, when I inquired into the material techniques that fabricated this thing's differentiation, I found myself driven back to the human and non-human things it assembles and, consequently, confronted with a choice about which assemblages to notice and the jurisdictional practices that underpin those choices. This analysis may mean this thing is law. Or it may mean that materiality cannot be how the differentiation of law, specifically, is fabricated.

Thus, although a materialist approach might dodge the perpetual contextualising currently fashionable in legal history, it does not escape the social and jurisdictional forces that underpin how material becomes meaningful. The upshot is not the revival of a quixotic quest for 'society', but rather a more humble affirmation of the fact of plural, collective relations among humans and non-humans. We find ourselves back at a processual, technical question of how human and non-human are drawn together in ways for matter to matter.

Oedipus, on his way to Thebes, encountered the monster that had been laying siege to Thebes and killing travellers stumped by its riddles. The Sphinx asked Oedipus, 'What walks on four legs in the morning, on two at noon, and on three in the evening?' 'Man,' answered Oedipus, thus saving Thebes and provoking the Sphinx's death. Our object, a 'Haida sphinx', was dislocated from place and kin in the aftermath of a deadly epidemic and swept up into a museum collection on the wave of a colonial science that arrayed the stages of 'Man' from primitive to European. Anthropology, like modern Western law, strives to overcome ignoble origins in colonialism. In what some hope will deal the coup de grâce to 'Man' that structuralism and post-structuralism failed to land, the present turn to materialism focuses on 'things', distributed agencies and non-human vitalities, and plural ontologies and jurisdictions. Meanwhile, in our midst, sits this object, enmeshed in silences and absences, waiting for the riddle to be solved. 